Applied Physiology, Nutrition, and Metabolism

Canadian Science Publishing Physiologie appliquée, nutrition et métabolisme

\title{
Sex-related differences in fuel utilization and hormonal response to exercise: implications for individuals with type 1 diabetes
}

\begin{tabular}{|r|l|}
\hline Journal: & Applied Physiology, Nutrition, and Metabolism \\
\hline Manuscript ID & apnm-2017-0559.R1 \\
\hline Manuscript Type: & Review \\
\hline Date Submitted by the Author: & 28-Nov-2017 \\
\hline Keyplete List of Authors: & $\begin{array}{l}\text { Brockman, Nicole; University of Alberta, Augustana Faculty } \\
\text { Yardley, Jane; University of Alberta, Augustana Faculty; Alberta Diabetes } \\
\text { Institute }\end{array}$ \\
\hline $\begin{array}{r}\text { Is the invited manuscript for } \\
\text { consideration in a Special } \\
\text { Issue? : }\end{array}$ & $\begin{array}{l}\text { N/A diabetes, sex-related differences, fuel selection, physical activity < } \\
\text { exercise }\end{array}$ \\
\hline
\end{tabular}

SCHOLARONE ${ }^{\text {W }}$

Manuscripts 
Sex-related differences in fuel utilization and hormonal response to exercise: implications for individuals with type 1 diabetes

Nicole K. Brockman ${ }^{1}$, Jane E. Yardley ${ }^{2,3}$

${ }^{1}$ University of Alberta, Augustana Faculty, Camrose, AB, Canada (nbrockma@ualberta.ca)

${ }^{2}$ University of Alberta, Augustana Faculty, Camrose, AB, Canada (jeyardley@ualberta.ca)

${ }^{3}$ Physical Activity and Diabetes Laboratory, Alberta Diabetes Institute

\section{Corresponding Author:}

Jane E Yardley, PhD

Assistant Professor, Social Sciences

University of Alberta, Augustana Faculty

4901 - 46th Avenue

Camrose, AB, T4V 2R3

(780) 679-1688 (phone)

(780) 679-1590 (fax)

Email: jane.yardley@ualberta.ca 


\begin{abstract}
Sex-related differences in metabolic and neuroendocrine response to exercise in individuals without diabetes have been well established. Men and women differ in fuel selection during exercise, in which women rely to a greater extent on fat oxidation, whereas males rely mostly on carbohydrate oxidation for energy production. The difference in fuel selection appears to be mediated by sex-related differences in hormonal (including catecholamines, growth hormone, and estrogen) response to different types and intensities of exercise. In general, men exhibit an amplified counter-regulatory response to exercise, with elevated levels of catecholamines compared to women. However, women exhibit greater sensitivity to the lipolytic action of the catecholamines and deplete less of their glycogen stores than men during exercise, which suggests that women may experience a greater defense in blood glucose control after exercise than men. Conversely, little is known about sex-related differences in response to exercise in individuals with type 1 diabetes (T1D). A single study investigating sex-related differences in response to moderate aerobic exercise in individuals with T1D found sex-related differences in catecholamine response and fuel selection, but changes in blood glucose were not measured. To our knowledge, there are no studies investigating sex-related differences in blood glucose responses to different types and intensities of exercise in individuals with T1D. This review summarizes sex-related differences in exercise responses that could potentially impact blood glucose levels during exercise in individuals with T1D and highlights the need for further research.
\end{abstract}

Key words: physical activity, type 1 diabetes, sex-related differences, fuel selection 


\section{Introduction}

Traditionally, exercise studies have excluded women due to the potential impact of fluctuating hormones caused by the menstrual cycle. Thus, the majority of what we know regarding exercise physiology pertains mostly to men. Recently, there has been an increasing amount of studies that have sought to include both male and female participants, and sex-related differences in exercise have been more widely established. Studies comparing the neuroendocrine and metabolic responses to exercise in nondiabetic males and females have shown clear sex-related differences in fuel selection (Horton et al. 1998; Davis et al. 2000b; Galassetti et al. 2002; Mittendorfer et al. 2002; Steffensen et al. 2002; Riddell et al. 2003; Henderson et al. 2007; Tarnopolsky 2008; Fragala et al. 2011; Isacco et al. 2012; Hedrington and Davis 2015; Devries 2016; Wiecek et al. 2017) and the responses of hormones such as catecholamines (Amiel et al. 1993; Gratas-Delamarche et al. 1994; Horton et al. 1998; Davis et al. 2000b; Pullinen et al. 2002; Steffensen et al. 2002; Hedrington and Davis 2015; Justice et al. 2015), testosterone (Kraemer et al. 1998; Nindl et al. 2001; Linnamo et al. 2005; Fragala et al. 2011; Benini et al. 2015), estrogen (Horton et al. 1998; Hamadeh et al. 2005; Devries et al. 2006; Isacco et al. 2012) and growth hormone (Davis et al. 2000b; Esbjörnsson et al. 2009; Eliakim et al. 2014; Luk et al. 2015). These factors influence how women and men respond to the same exercise program, and have thus brought about the suggestion for sex-specific training protocols to enhance health and performance (Devries 2016).

While there is extensive research on exercise in individuals without diabetes, very little is known about sex-related differences in response to exercise in individuals with type 1 diabetes (T1D). Most studies on exercise in T1D are performed on men (Wahrenberg et al. 1989; Purdon et al. 1993; Ramires et al. 1993; Raguso et al. 1995; Bussau et al. 2007; Chokkalingam et al. 2007; Jenni et al. 2008; Maran et al. 2010; Benbenek-Klupa et al. 2015; Campbell et al. 2015a; Moser et al. 2015; Bally et al. 2016), and those that include both men and women fail to recognize the potential sex-related differences in neuroendocrine and metabolic responses to exercise (Zinman et al. 1977; Hubinger et al. 1985; McGregor et al. 2002; Guelfi et al. 2005; Robitaille et al. 2007; Arutchelvam et al. 2009; Iscoe and Riddell 2011; Adolfsson et al. 2012; Dube et al. 2013; Yardley et al. 2013; Yardley et al. 2014; Campbell et al. 2015b; Yardley et al. 
2015). These differences have the potential to greatly impact the counter-regulatory response to exercise, possibly resulting in differing abilities between the sexes to maintain blood glucose homeostasis (Galassetti et al. 2002). Thus, sex-related differences are an important factor to take into consideration when assessing the risk of hypoglycemia both during and after exercise in T1D. This review summarizes current knowledge on the topic of sex-related differences in exercise responses in nondiabetic individuals that may be relevant when considering the risk of hypoglycemia in individuals with T1D. Understanding sex-related differences in exercise for T1D could assist in creating sex-specific exercise guidelines to reduce the risk of hypoglycemia during and after exercise.

\section{Methods}

A narrative review approach was used to investigate the current literature on sex-related differences in exercise in individuals with and without T1D. We searched the following databases for the period January 1977 to October 2017: PubMed, MEDLINE, EMBASE, Sport Discus, and Google Scholar.

We used the following key words for the search: sex-related differences, sexual dimorphism, sex differences, exercise, physical activity, resistance exercise, high-intensity exercise, moderate exercise, aerobic exercise, anaerobic exercise, endurance exercise, fuel selection, fuel utilization, hormonal response, diabetes, type 1 diabetes, IDDM, glucose, blood glucose, glycemia, hypoglycemia, nocturnal hypoglycemia, glycogen depletion, catecholamine, growth hormone, IGF-1, insulin, glucagon, estrogen, menstrual cycle, menstrual cycle phase, follicular phase, luteal phase, and counter-regulatory response. All searches were limited to humans.

Studies were retained if they examined the effect of an acute bout of exercise on fuel utilization or hormonal response in men, women, or both sexes in individuals with and without type 1 diabetes. No study was excluded due to study design (e.g., laboratory-based studies, review articles, systematic reviews...etc.). Studies were excluded if they did not report on fuel selection, blood glucose or counterregulatory hormones such as insulin, glucagon, epinephrine, norepinephrine, growth hormone and IGF-1, or if they were not available in the English language. 


\section{Discussion}

\section{Fuel Selection}

\section{Individuals without Diabetes}

There are marked sex-related differences in fuel selection during exercise in nondiabetic individuals. Although there is no apparent difference between sexes in fuel selection in the resting state (Tremblay et al. 2010; Sarafian et al. 2016), it has been widely accepted that during exercise females exhibit a lower respiratory exchange ratio (RER), thus relying to a greater extent on fat oxidation whereas men rely mostly on carbohydrate oxidation for energy production (Horton et al. 1998; Davis et al. 2000b; Carter et al. 2001; Galassetti et al. 2002; Mittendorfer et al. 2002; Steffensen et al. 2002; Riddell et al. 2003; Henderson et al. 2007; Tarnopolsky et al. 1990; Fragala et al. 2011; Isacco et al. 2012; Hedrington and Davis 2015; Devries 2016; Wiecek et al. 2017). This trend has been established for nondiabetic males and females during aerobic exercise (Horton et al. 1998; Davis et al. 2000b; Carter et al. 2001; Mittendorfer et al. 2002; Riddell et al. 2003; Tarnopolsky et al. 1990; Isacco et al. 2012; Henderson 2014; Hedrington and Davis 2015; Devries 2016; Wiecek et al. 2017), high intensity exercise (Isacco et al. 2012) and resistance exercise (Fragala et al. 2011; Sarafian et al. 2016). Additionally, men demonstrate an earlier shift to using carbohydrates as the dominant fuel source compared to women, particularly during high intensity exercise (Venables et al. 2005).

While there are conflicting reports, the majority of studies show that a lower reliance on carbohydrate oxidation during exercise by women is related to less depletion of hepatic and muscle glycogen (Horton et al. 1998; Esbjörnsson-Liljedahl et al. 1999; Devries et al. 2006; Isacco et al. 2012). This tendency appears to be related to type and intensity of the exercise performed and/or the phase of the menstrual cycle in which the exercise is performed. Studies reporting no difference in glycogen depletion between sexes involved submaximal exercise (Table 1) on a cycle ergometer in the follicular phase of the menstrual cycle (Roepstorff et al. 2002; Zehnder et al. 2005). Investigating the relationship between phase of the menstrual cycle and glycogen depletion, Devries et al. (2006) found that submaximal exercise performed on a cycle ergometer by women in the luteal phase of the menstrual cycle, as opposed to the 
follicular phase, resulted in less depletion of glycogen stores compared with men. Additionally, during higher intensity exercise such as sprints (Esbjörnsson-Liljedahl et al. 1999), running (Tarnopolsky et al. 1990), or during long duration endurance exercise (Horton et al. 1998), males appear to deplete a greater portion of their glycogen stores than females (Table 2). The type of muscle fibers recruited during exercise may also play a role: a study by Esbjörnsson-Liljedahl et al. (1999) comparing the metabolic responses to a 30-s sprint exercise in males and females, matched for age and activity level, showed that the exercise-induced muscle glycogen reduction was significantly smaller in women than in men in type 1 , but not type II fibers.

Lipid metabolism appears to be greater in females than in males in adipose tissue, and potentially working skeletal muscle. During exercise, women exhibit higher glycerol release from adipose tissue compared to men (Davis et al. 2000b; Carter et al. 2001; Mittendorfer et al. 2002; Steffensen et al. 2002; Hedrington and Davis 2015). In working skeletal muscle, it has been contested whether women use more intramyocellular lipids (IMCL) during exercise than men. It is known that women have greater IMCL stores than men (Devries 2016), and the majority of studies show that females use more IMCL during exercise than males (Roepstorff et al. 2002; Steffensen et al. 2002). Two studies conducted on recreationally active individuals without diabetes performing submaximal exercise at $60 \% \mathrm{VO}_{2}$ max on a cycle ergometer resulted in oxidation of IMCL in females, but not in males (Roepstorff et al. 2002; Steffensen et al. 2002). However, some studies have found equal (Devries et al. 2007) or lesser (Zehnder et al. 2005) use of IMCL during exercise in females. Despite this, women have exhibited a greater percentage of IMCL in contact with mitochondria after exercise than men, which indicates the greater capacity for women to oxidize IMCL during exercise (Devries 2016).

The sex-related difference in fuel selection disappears when a carbohydrate load precedes exercise (Riddell et al. 2003; Leelayuwat et al. 2005; Wallis et al. 2006), which may be of particular relevance to individuals with T1D who often consume carbohydrates prior to exercise. Almost all studies showing sex-related differences in fuel selection occurred during exercise in the fasted state (Horton et al. 1998; Davis et al. 2000b; Carter et al. 2001; Mittendorfer et al. 2002). Studies on males and females in the 
postprandial state showed similar substrate oxidation and other metabolic responses between sexes during submaximal exercise on a cycle ergometer, when subjects were infused with glucose for 60 minutes (Leelayuwat et al. 2005) or ingested a glucose solution (Wallis et al. 2006) preceding exercise.

Carbohydrate intake largely eliminated sex-related differences in whole-body substrate oxidation. Riddell at al. (2003) also found this to be true in endurance exercise, in which there was a greater reliance on exogenous carbohydrates in women compared to men after 90 minutes of exercise on a cycle ergometer at $60 \% \mathrm{VO}_{2}$ max. This ability for women to spare endogenous fuel sources compared to men may assist women in maintaining better blood glucose homeostasis during exercise.

\section{Implications for type 1 diabetes}

Similar sex-related differences with respect to fuel selection have been observed in individuals with T1D during moderate aerobic exercise (Galassetti et al. 2002), where women showed attenuated catecholamine responses and greater use of lipids as a fuel source. The study in question, however, used a euglycemic clamp, thereby precluding the possibility of assessing changes in blood glucose. If sex-related differences do exist in blood glucose responses to exercise in T1D, it is likely that men will have a greater risk of post-exercise hypoglycemia: due to the fact that men rely more on their glycogen stores during exercise than women a greater uptake of plasma glucose will be needed to replenish depleted glycogen stores in the recovery period (Devries et al. 2006; Yardley et al. 2013). Conversely, where women are better able to conserve glycogen stores, there will be less need for a large uptake of plasma glucose in the recovery period (Horton et al. 1998; Esbjörnsson-Liljedahl et al. 1999; Devries et al. 2006; Isacco et al. 2012). Women without diabetes have displayed a more precise defense of homeostasis in the postexercise recovery period, including the control of fuel selection and blood glucose concentration (Henderson et al. 2008; Henderson 2014). Due to their greater capacity for lipid oxidation during exercise, women are able to regain control over glycemia and glucose flux in recovery more quickly than men (Henderson et al. 2008). As a result, men often show an elevated rate of lipid mobilization postexercise compared to women, in attempt to preserve glucose concentrations when restoring glycogen stores depleted from exercise (Horton et al. 1998; Henderson et al. 2007). 


\section{Catecholamines}

\section{Individuals without Diabetes}

There is an evident sex-related difference in catecholamine response to various types and intensities of exercise. While there are studies that report no sex-related differences in catecholamine response to a Wingate test (30-s maximum sprint on a cycle ergometer) in recreationally active individuals (Vincent et al. 2004), and to 14 minutes of anaerobic exercise to exhaustion in moderately trained individuals (Marliss et al. 2000), the majority of studies report a significantly greater catecholamine response to various types of exercise in males compared to females (Amiel et al. 1993; Gratas-Delamarche et al. 1994; Horton et al. 1998; Davis et al. 2000b; Pullinen et al. 2002; Steffensen et al. 2002; Hedrington and Davis 2015; Justice et al. 2015). Davis et al. (2000b) matched men and women for age, BMI, fitness level and fat mass and found significantly elevated epinephrine and norepinephrine concentrations in men compared to women during moderate aerobic exercise on a cycle ergometer in the fasted state (Davis et al. 2000b). The same results were found in a similar study on participants in the postprandial state, in which men had significantly higher epinephrine levels compared to women during moderate aerobic exercise on a cycle ergometer (Steffensen et al. 2002). Horton et al. (1998) compared the metabolic effects of endurance exercise on a cycle ergometer for $2 \mathrm{~h}$ at $40 \% \mathrm{VO}_{2} \max$ in men and women, which showed that long duration aerobic exercise also produces significantly greater epinephrine and norepinephrine levels in men than in women (Horton et al. 1998). High intensity and resistance exercise (Table 3), which elicit substantially higher levels of catecholamines compared to aerobic exercise, also display the same sex-related differences as moderate intensity and endurance exercise (Pullinen et al. 2002; Justice et al. 2015).

While men have exhibited an elevated catecholamine response to exercise compared to women, there is an apparent sex-related difference in sensitivity of lipolytic activity to catecholamines during exercise. Catecholamines increase lipolysis during exercise, and thus higher lipolytic rates in males would be expected compared to females, due to their higher catecholamine response (Horton et al. 1998; Hedrington and Davis 2015). However, an endurance exercise study consisting of $2 \mathrm{~h}$ of cycling at $40 \%$ 
$\mathrm{VO}_{2} \max$ found that there was no difference between the sexes in circulating levels of glycerol, an indicator of whole body lipolysis, despite an elevated catecholamine response in men (Horton et al. 1998). Further studies observed the same phenomenon (Steffensen et al. 2002; Isacco et al. 2012; Hedrington and Davis 2015), and thus elevated levels of lipolysis in women despite lower levels of catecholamines than men imply a greater sensitivity to the lipolytic action of the catecholamines in women. It is suggested that women have a higher $\beta$-adrenergic sensitivity, which would stimulate lipolysis, and decreased $\alpha$-adrenergic sensitivity, which would inhibit lipolysis, compared to men (Steffensen et al. 2002; Isacco et al. 2012; Schmidt et al. 2014; Hedrington and Davis 2015). While both $\alpha$-adrenergic and $\beta$-adrenergic receptors are activated in men to a relatively equal extent during exercise, women have a greater sensitivity to $\beta$-adrenergic receptors, resulting in greater net lipolysis (Hedrington and Davis 2015). To examine this, Schmidt et al. (2014) investigated the sex-related differences in the relative contribution of specific adrenergic receptors in metabolic responses. Epinephrine infusion resulted in greater lipolytic responses in women compared to men, leading to the conclusion that there was lower activation of the $\alpha$-adrenergic receptors in women (Schmidt et al. 2014). Thus, during exercise when epinephrine is elevated, women have relatively greater lipolysis and fat oxidation than men.

\section{Implications for type 1 diabetes}

Individuals with T1D appear to display the same sex-related differences in catecholamine response to exercise as nondiabetic individuals. Galassetti et al. (2002) found that after 90 minutes of aerobic exercise on a cycle ergometer at $50 \% \mathrm{VO}_{2} \max$, epinephrine and norepinephrine responses to exercise were greater in men compared to women with T1D (Galassetti et al. 2002). However, the elevated catecholamine response in men was not paralleled by a higher lipolytic rate (Galassetti et al. 2002). In fact, lipolytic responses and circulating glycerol were higher in women compared to men during exercise. This may indicate that women with T1D display the same greater sensitivity to $\beta$-adrenergic effects and diminished activation of $\alpha$-adrenergic receptors as do nondiabetic females (Galassetti et al. 2002). Whether this results in sex-related differences in blood glucose changes during and after exercise is unknown, as the study in question used a euglycemic clamp, and was thus unable to measure changes 
in blood glucose. Galassetti et al. (2002) did, however, find that despite the sex-related differences in catecholamine response in T1D individuals, there was no difference in endogenous glucose production or the need for exogenous glucose. Further research is needed to determine the effect this would have on blood glucose changes and the risk of hypoglycemia during and after exercise in individuals with T1D.

\section{Estrogen}

\section{Individuals without Diabetes}

The female sex hormone, estrogen, is a contributing factor in influencing fuel selection during exercise in men and women. Estrogen, specifically $17 \beta$-estradiol, promotes lipid oxidation and decreases carbohydrate oxidation during exercise (Horton et al. 1998; Hamadeh et al. 2005; Devries et al. 2006; Isacco et al. 2012). In a study aimed to determine the effect of $17 \beta$-estradiol supplementation on glucose kinetics and substrate use, Devries et al. (2005) recruited recreationally active young men to receive either placebo or $17 \beta$-estradiol orally for eight days. Following this supplementation, participants exercised for 90 min on a cycle ergometer at $65 \% \mathrm{VO}_{2}$ max. Compared to the control placebo group, men supplemented with $17 \beta$-estradiol had a lower RER and therefore less carbohydrate oxidation, with significantly higher lipid oxidation (Devries et al. 2005). A similar study by Hamadeh et al. (2005) had parallel results, with estrogen supplementation resulting in a shift in whole body RER, carbohydrate and lipid oxidation towards the patterns found in women (Hamadeh et al. 2005).

Different phases of the menstrual cycle can also influence metabolism during exercise. Due to fluctuating hormone levels, women display differing metabolic responses to exercise depending on the phase of the menstrual cycle in which they were tested. Most studies test women in the early follicular phase, as during this phase of the menstrual cycle estrogen concentrations are relatively stable and do not differ markedly between men and women (Fragala et al. 2011). This limits the influence that estrogen could have on fuel selection during exercise. During the luteal phase of the menstrual cycle, there is a higher level of circulating estrogen and thus a higher relative rate of fat oxidation in females during exercise (Riddell et al. 2003). Devries et al. (2006) investigated the effects that different concentrations of estrogen and progesterone during the luteal and follicular phases of the menstrual cycle have on fuel 
selection during exercise. Recreationally active young women and men underwent 90 min of exercise on a cycle ergometer at $65 \% \mathrm{VO}_{2} \max$. The female participants were split into two groups, with half testing in the follicular phase and half in the luteal phase. Results showed that women in the luteal phase had lower glucose appearance and disappearance rates as well as glycogen use than women testing in the follicular phase (Devries et al. 2006). In addition, both groups of females displayed a lower RER than men during exercise, indicating a greater reliance on lipids as a fuel source.

While circulating levels of estrogen do not differ significantly between the sexes during the follicular phase of the menstrual cycle, women often experience an elevation in circulating estradiol following an acute bout of exercise, whereas men do not (Consitt et al. 2002; Fragala et al. 2011). This has occurred in studies involving resistance exercise (Kraemer et al. 1995; Copeland et al. 2002) and aerobic exercise (Jurkowski et al. 1978; Copeland et al. 2002) in both the luteal (Jurkowski et al. 1978; Kraemer et al. 1995; Copeland et al. 2002) and follicular phase (Jurkowski et al. 1978; Kraemer et al. 1995) of the menstrual cycle. The magnitude of increase in estradiol to an acute bout of exercise is also significantly greater in the luteal phase compared to the follicular phase (Jurkowski et al. 1978; Kraemer et al. 1995; Consitt et al. 2002). This exercise-induced increase in estradiol can result in a greater contribution of fat oxidation to energy production during exercise in females compared to males.

Though it is apparent that levels of estrogen can affect metabolism during exercise, estrogen does not appear to be the sole determinant for fuel selection in females. Numao et al. (2009) compared substrate oxidation during moderate-intensity aerobic exercise in obese men and postmenopausal obese women. At rest and during exercise, there was no significant difference between the sexes in concentrations of $17 \beta$-estradiol. Despite this, RER was still lower in women than in men during exercise, indicating a higher rate of lipolysis. These results suggest that an elevated level of lipolysis in women does not depend solely on higher levels of $17 \beta$-estradiol.

\section{Implications for type 1 diabetes}

Higher estrogen levels in women with T1D compared to men with T1D could offer a mechanism for control over glucose homeostasis during exercise. The enhanced lipolytic rate and attenuated 
carbohydrate oxidation associated with elevated estrogen levels might be a means for conserving plasma glucose and glycogen stores, thus resulting in less risk of hypoglycemia, particularly post-exercise when stores are being replenished (Devries et al. 2006; Yardley et al. 2013). Furthermore, the phase of the menstrual cycle could influence blood glucose control during exercise. Studies have shown that women exercising in the luteal phase (which is associated with higher levels of estrogen) compared to the follicular phase of the menstrual cycle experienced less glycogen depletion (Devries et al. 2006), higher lipid and lower carbohydrate oxidation (Isacco et al. 2012) and greater concentrations of blood glucose (Zderic et al. 2001). While it has not been studied in individuals with T1D, exercising in the luteal phase could offer a greater defense against hypoglycemia during and after exercise for women with T1D. Further research is needed to investigate the effects that estrogen levels and phases of the menstrual cycle have on blood glucose control during exercise in individuals with T1D to determine their impact on exercise-induced hypoglycemia.

\section{Growth Hormone}

\section{Individuals without Diabetes}

There is a lack of consensus regarding sex-related differences in growth hormone response to exercise. Some studies report a significantly higher growth hormone response in men compared to women after sprint (Justice et al. 2015), aerobic exercise (Vislocky et al. 2008; Tarnopolsky et al. 1990; Henderson et al. 2007) or resistance exercise (Linnamo et al. 2005), while others report a greater growth hormone response in women after resistance exercise (Luk et al. 2015) or sprints (Eliakim et al. 2014). The majority of studies, however, report a similar response in males and females in which both sexes experience a similar relative increase in growth hormone levels during and following exercise that lasts longer than 10 minutes (Kraemer et al. 1991; Davis et al. 2000b; Consitt et al. 2002; Esbjörnsson et al. 2009; Benini et al. 2015, Pullinen et al. 2002).

Despite the similar absolute increase in growth hormone levels that most studies report, males and females exhibit a different pattern of growth hormone release during exercise. Studies report higher growth hormone peaks in women, that appear sooner and return to baseline more quickly (Davis et al. 
2000b; Esbjörnsson et al. 2009) while men sustain a more prolonged response (Davis et al. 2000b; Esbjörnsson et al. 2009; Eliakim et al. 2014; Luk et al. 2015). These sex-related differences in growth hormone response can be attributed to a lack of testosterone response in women (Consitt et al. 2002). Women experience little or no increase in testosterone levels in response to exercise (Kraemer et al. 1991; Enea et al. 2011; Fragala et al. 2011), thus growth hormone appears to compensate for the anabolic requirements stimulated by acute exercise (Kraemer et al. 1993; Fragala et al. 2011). Furthermore, women have a higher resting basal level of growth hormone than men (Kraemer et al. 1998; Wideman et al. 1999; Consitt et al. 2002), particularly in the early follicular phase of the menstrual cycle (Kraemer et al. 1991). Since most exercise studies are performed on women during the early follicular phase of the menstrual cycle (due to low levels of estrogen in this phase), there are marked sex-related differences in basal growth hormone levels (Fragala et al. 2011), and subsequently often higher peaks of growth hormone in women during exercise (Davis et al. 2000b; Esbjörnsson et al. 2009; Luk et al. 2015). Additionally, estrogen is known to release a growth hormone stimulating factor (Consitt et al. 2002), and thus elevated levels of circulating estrogen are associated with higher growth hormone concentrations (Luk et al. 2015). When examining growth hormone response to exercise, it is important to take into consideration insulin-like growth factor-1 (IGF-1), a hormone similar in structure to insulin that mediates many actions of growth hormone (Kraemer et al. 1991). The growth hormone-insulin-like growth factor-1 (GH-IGF-1) axis primarily regulates fundamental growth, development, metabolic and reparative processes, but has also been suggested to mediate many of the anabolic effects associated with aerobic, anaerobic and resistance exercise (Eliakim et al. 2014). Growth hormone and IGF-1 have a bi-directional relationship, in which growth hormone stimulates IGF-1, and IGF-1 feedback inhibits growth hormone (Frystyk 2004). However, during exercise, IGF-1 levels appear to be independent of growth hormone responses (Consitt et al. 2002). There has been inconsistency in reports of IGF-1 response to exercise, with studies showing increases, decreases, and no changes in circulating total IGF-1 (Gatti et al. 2012). It appears that IGF-1 response to exercise depends on type, intensity and duration of exercise, with most studies reporting a 
significant increase in IGF-1 using a high-intensity constant-power exercise stimulus (Copeland and Heggie 2008).

It is contested whether sex-related differences exist in IGF-1 response to exercise. One study found that in response to an acute bout of high-intensity anaerobic exercise, there was a significant increase in IGF-1 in males but not females, however, there were no significant between-sex effects (Eliakim et al. 2014). Other studies have found no differences between sexes in response to 10 minutes of high-intensity cycling, with short term elevations in IGF-1 in both males and females (Bang et al. 1990; Cappon et al. 1994). The increase in IGF-1 in response to 10 minutes of high-intensity cycling also does not appear to depend on the phase of the menstrual cycle that females are tested in (Hornum et al. 1997). Additionally, a study investigating IGF-1 response to ultra-endurance exercise found no sex-related differences between males and females, with slight decreases in IGF-1 levels occurring similarly in both males and females (Berg et al. 2008).

The marked sex-related difference in growth hormone response to exercise can influence blood glucose control in males and females. Increases in growth hormone stimulate lipolysis and lipid oxidation, suppressing glucose oxidation and consequently increasing plasma glucose levels (Kraemer et al. 1991). Thus, higher resting levels of growth hormone in women due to higher levels of estrogen may preserve plasma glucose levels to a greater extent in women than in men. In terms of IGF-1 and glucose response, studies have shown that treatment of IGF-1 lowers plasma glucose in subjects with and without T1D, however, it is unclear to what extent endogenous IGF-1 participates in glucose homeostasis (Frystyk 2004).

\section{Implications for type 1 diabetes}

Although studies are limited, individuals with T1D do not appear to display the same sex-related differences in growth hormone response to exercise as nondiabetic males and females. In individuals with T1D, Galassetti et al. (2002) found that the growth hormone response was significantly lower in women compared to men following an acute bout of submaximal exercise (Galassetti et al. 2002). However, women still exhibited a greater lipolytic response, suggesting the possibility of greater tissue sensitivity to 
growth hormone in women than in men. It remains unknown why women with T1D appear to produce a lower growth hormone response to exercise than nondiabetic women, and further studies are needed to investigate this phenomenon.

Individuals with T1D have impairment of the GH-IGF-1 axis, characterized by exaggerated exercise-induced growth hormone and lower IGF-1 levels, as a consequence of insulin deficiency, compared to the general population (Palta et al. 2014; Jenni et al. 2010; Frystyk 2004; Tonoli et al. 2014). A study investigating the effects of an acute bout of high intensity exercise on a cycle ergometer found that at all time points, individuals with T1D has significantly lower IGF-1 levels than individuals without T1D (Tonoli et al. 2014). However, this study found that T1D does not influence the IGF-1 response to acute high-intensity exercise, with comparable increasing effects on IGF-1 found in T1D and non-T1D.

It is unknown whether sex-related differences exist in IGF-1 response to exercise in individuals with T1D. If they did, this could have important implications for blood glucose levels. IGF-1 is necessary for normal insulin sensitivity; it binds to insulin receptors to stimulate glucose transport while simultaneously inhibiting glucose release from the liver and lowering blood glucose levels (Tonoli et al. 2014). Thus, decreased IGF-1 levels could diminish the homeostasis of glucose metabolism. As mentioned, however, it is unknown to what extent endogenous IGF-1 affects blood glucose levels (Frystyk 2004) and whether or not sex-related differences exist. Further elucidation is therefore required.

\section{Insulin Sensitivity}

\section{Individuals without Diabetes}

It has been contested whether or not there are sex-related differences in insulin sensitivity in response to exercise. Some studies have found that men and women experience a similar improvement of insulin sensitivity in response to an acute bout of exercise on a cycle ergometer for 90 minutes at $80 \%$ of anaerobic threshold (Davis et al. 2000b) or for 60 minutes at $50 \% \mathrm{VO}_{2} \mathrm{max}$ after either receiving a glucose infusion or an oral ingestion of a high-carbohydrate meal (Leelayuwat et al. 2005). Conversely, other studies have found that women experience a greater improvement of insulin sensitivity in response to 90 minutes of submaximal exercise on a cycle ergometer at $86 \%$ of lactate threshold under a 
hyperinsulinemic-euglycemic clamp (Perreault et al. 2004), or to 30 minutes of cycling exercise at $60 \%$ $\mathrm{VO}_{2}$ max following an oral ingestion of a glucose solution (Boisseau et al. 2000). Furthermore, the phase of the menstrual cycle that women are tested in may also have an impact on insulin sensitivity during exercise. Studies by Pulido and Salazar (1999) and Valdes and Elkind-Hirsch (1991) found that there was a significant decrease in insulin sensitivity in women during the luteal phase of the menstrual cycle compared to the follicular phase, though this was not tested under exercise conditions.

\section{Implications for type 1 diabetes}

Sex-related differences in insulin sensitivity in individuals with T1D in response to exercise are unknown. If they existed, differences in insulin sensitivity could result in differing abilities to maintain blood glucose levels during exercise. Increases in insulin sensitivity are related to an increased risk of post-exercise hypoglycemia in individuals with T1D (Jimenez et al. 2009). Furthermore, depletion of skeletal muscle glycogen stores is positively correlated with exercise intensity (Hougham and Ross 2011), and exercise intensity has been associated with improved insulin sensitivity (Black et al. 2010; Hougham and Ross 2011). Because most studies have shown a greater glycogen depletion in men (Horton et al. 1998; Esbjörnsson-Liljedahl et al. 1999; Devries et al. 2006; Isacco et al. 2012), this may result in a higher insulin sensitivity in men. Thus, men, especially those of higher fitness levels, might have a greater risk of experiencing hypoglycemia during and after exercise than women. Additionally, similar to women without diabetes, women with T1D experience decreased insulin sensitivity during the luteal phase of the menstrual cycle compared to the follicular phase, resulting in an increased risk of hyperglycemia during this phase (Brown et al. 2015). However, the impact this would have on blood glucose levels during exercise is unknown, and further studies are warranted to investigate the potential implications. It is also important to note that while insulin sensitivity plays a role in blood glucose control during and after exercise, this role is minor compared to the levels of circulating exogenous insulin in individuals with T1D. The risk of hypoglycemia as a result of exercise-induced insulin sensitivity is greatly diminished by the reduction of basal insulin before exercise (Thabit and Leelarathna 2016) in individuals with T1D.

\section{Glucagon}




\section{Individuals without Diabetes}

There are conflicting reports regarding glucagon response to exercise in nondiabetic men and women. A study by Davis et al. (2000b) reported a similar increase in plasma glucagon in both sexes following 90 minutes of continuous submaximal exercise on a cycle ergometer at $80 \%$ of anaerobic threshold (Davis et al. 2000b). Similar results were also reported in a study by Justice et al. (2015), in which, after repeated bouts of high intensity sprints, there was no main effect of sex on changes in plasma glucagon concentrations (Justice et al. 2015). However, other studies have reported a lower glucagon response to exercise in females compared to males exercising on a cycle ergometer at $\sim 50 \% \mathrm{VO}_{2} \mathrm{max}$ (Perreault et al. 2004; Horton et al. 2006a; Tarnopolsky et al. 1990; Henderson et al. 2008). Nevertheless, in all studies, despite some differences reported in magnitude, both males and females showed an increase in glucagon production in response to exercise.

\section{Implications for type 1 diabetes}

Type 1 diabetes is associated with $\beta$-cell death that is accompanied by a loss of $\alpha$-cell function over time (Banarer et al. 2002), thus impairing the counter-regulatory responses to episodes of stress, including glucagon response to hypoglycemia (Davis et al. 2000a; Galassetti et al. 2002). The impaired glucagon response appears to happen evenly between the sexes, with no reported sex-related differences in glucagon response to exercise in T1D. Galassetti et al. (2002) investigated the metabolic responses to submaximal exercise in individuals with T1D and found that both males and females experienced similar increases in glucagon. Thus, glucagon does not appear to contribute to sex-related differences in blood glucose control during exercise in individuals with T1D.

\section{Conclusion}

There are well known sex-related differences in exercise in individuals without diabetes. Females display a lower RER during exercise, relying to a greater extent on lipid oxidation whereas males rely more on carbohydrate oxidation. This could be the result of higher concentrations of estrogen in females, which promotes lipid oxidation and glycogen sparing, as well as a greater sensitivity to the lipolytic action of catecholamines. Furthermore, elevated resting levels of growth hormone and greater peaks in 
growth hormone response to exercise in women could be a contributing factor to the sex-related differences in fuel utilization.

Sex-related differences in response to different types of exercise in individuals with T1D remain unclear. While knowledge is limited, a single study investigating the sex-related differences in submaximal exercise in individuals with T1D has paralleled the sex-related differences found in individuals without diabetes with respect to fuel selection and catecholamine response (Galassetti et al. 2002). However, this study used a euglycemic clamp to maintain blood glucose levels during exercise, and thus blood glucose responses to exercise were not measured. Furthermore, one study is not enough to draw conclusions on sex-related differences in exercise in T1D.

Overall, we do not know whether there are significant differences between men and women with T1D in response to different types and intensities of exercise, and whether this would influence blood glucose control. We can only speculate based on limited evidence that individuals with T1D would display the same sex-related differences as nondiabetic males and females, and that these might impact blood glucose responses to exercise. Further research is needed to investigate these possible sex-related differences in T1D, as this could have important implications for the development of sex-specific insulin adjustment and carbohydrate intake guidelines for the prevention of hypoglycemia during and after exercise.

\section{Acknowledgements}

NKB was supported by an Alberta Innovates Health Solutions Summer Studentship.

\section{Author Disclosure Statement}

JEY has received speaker's fees from Animas Canada, financial and in kind research support from Medtronic Canada, and in-kind research support from Ascensia Canada, Lifescan Canada, and Abbott Nutrition Canada (Glucerna). No competing financial interests exist for NKB. 


\section{References}

Adolfsson, P., Nilsson, S., Albertsson-Wikland, K., and Lindblad, B. 2012. Hormonal response during physical exercise of different intensities in adolescents with type 1 diabetes and healthy controls. Pediatr. Diabetes, 13(8): 587-96. doi:10.111/j.1399-5448.2012.00889.x. PMID:23173876.

Amiel, S.A., Maran, A., Powrie, J.K., Umpleby, A.M., and Macdonald, I.A. 1993. Gender differences in counterregulation to hypoglycaemia. Diabetologia, 36(5): 460-4. doi:10.1007/BF00402284.

PMID:8314452.

Arutchelvam, V., Heise, T., Dellweg, S., Elbroend, B., Minns, I., and Home, P.D. 2009. Plasma glucose and hypoglycaemia following exercise in people with type 1 diabetes: a comparison of three basal insulins. Diabet. Med. 26(1): 1027-32. doi:10.111/j.1464-5491.2009.02807.x. PMID:19900235. Bally, L., Zueger, T., Buehler, T., Dokumaci, A.S., Speck, C., Pasi, N., et al. 2016. Metabolic and hormonal response to intermittent high-intensity and continuous moderate intensity exercise in individuals with type 1 diabetes: a randomised crossover study. Diabetologia, 59(4): 776-84. doi:10.1007/s00125-015-3854-7. PMID:26739816.

Banarer, S., McGregor, V.P., and Cryer, P.E. 2002. Intraislet hyperinsulinemia prevents the glucagon response to hypoglycemia despite an intact autonomic response. Diabetes, 51(4): 958-65. doi:10.2337/diabetes.51.4.958. PMID:11916913. Bang, P., Brandt, J., Degerblad, M., Engberg, G., Kaijser, L., Thoren, M., et al. 1990. Exercise-induced changes in insulin-like growth factors and their low molecular weight binding protein in healthy subjects and patients with growth hormone deficiency. Eur. J. Clin. Invest. 20(3): 285-292. doi: 10.1111/j.13652362.1990.tb01857.x. PMID:1695151.

Benbenek-Klupa, T., Matejko, B., and Klupa, T. 2015. Metabolic control in type 1 diabetes patients practicing combat sports: at least two-year follow-up study. SpringerPlus, 4(1):133. doi:10.1186/s40064015-0919-5. PMID:25825689. 
Benini, R., Prado Nunes, P.R., Orsatti, C.L., Barcelos, L.C., and Orsatti, F.L. 2015. Effects of acute total body resistance exercise on hormonal and cytokines changes in men and women. J. Sports Med. Phys. Fitness, 55(4): 337-44. PMID:25853878.

Berg, U., Enqvist, J.K., Mattsson, C.M., Carlsson-Skwirut, C., Sundberg, C.J., Ekblom, B., et al. 2008. Lack of sex differences in the IGF-IGFBP response to ultra endurance exercise. Scand. J. Med. Sci. Sports, 18(6): 706-714. doi:10.1111/j.1600-0838.2007.00758.x. PMID:18248538.

Black, L.E., Swan, P.D., and Alvar, B.A. 2010. Effects of intensity and volume on insulin sensitivity during acute bouts of resistance training. J. Strength Cond. Res. 24(4): 1109-1116. doi:10.1519/JSC.0b013e3181cbab6d. PMID:20093961.

Boisseau, N., Delamarche, P., Rannou, F., Bentue-Ferrer, D., and Gratas-Delamarche, A. 2000. Effects of glucose ingestion at the onset of moderate-intensity, prolonged exercise in women as compared to men. Eur. J. Appl. Physiol. 81(1-2): 93-9. doi:10.1007/PL00013802. PMID:10552272.

Brown, S.A., Jiang, B., McElwee-Malloy, M., Wakeman, C., and Breton, M.D. 2015. Fluctuations of hyperglycemia and insulin sensitivity are linked to menstrual cycle phases in women with T1D. J. Diabetes Sci. Technol. 9(6): 1192-9. doi:10.1177/1932296815608400. PMID:26468135. Bussau, V.A., Ferreira, L.D., Jones, T.W., and Fournier, P.A. 2007. A 10-s sprint performed prior to moderate-intensity exercise prevents early post-exercise fall in glycaemia in individuals with type 1 diabetes. Diabetologia, 50(9): 1815-8. doi:10.1007/s00125-007-0727-8. PMID:17583795.

Campbell, M.D., Walker, M., Bracken, R.M., Turner, D., Stevenson, E.J., Gonzalez, J.T., et al. 2015a. Insulin therapy and dietary adjustments to normalize glycemia and prevent nocturnal hypoglycemia after evening exercise in type 1 diabetes: a randomized controlled trial. BMJ Open Diabetes Res. Care, 3(1): e000085. doi:10.1136/bmjdrc-2015-000085. PMID:26019878.

Campbell, M.D., West, D.J., Bain, S.C., Kingsley, M.I., Foley, P., Kilduff, L., et al. 2015b. Simulated games activity vs continuous running exercise: a novel comparison of the glycemic and metabolic responses in T1DM patients. Scand. J. Med. Sci. Sports, 25(2): 216-22. doi:10.111/sms/12192. PMID:24593125. 
Cappon, J., Brasel, J.A., Mohan, S.U., and Cooper, D.M. 1994. Effect of brief exercise on circulating insulin-like growth factor 1. J. Appl. Physiol. 76(6): 2490-2496. doi:10.1152/jappl.1994.76.6.2490. PMID:7928875.

Carter, S.L., Rennie, C., and Tarnopolsky, M.A. 2001. Substrate utilization during endurance exercise in men and women after endurance training. Am. J. Physiol. Endocrinol. Metab. 280(6): E898-907. doi:10.1152/ajpendo.2001.280.6.E898. PMID:11350771.

Chokkalingam, K., Tsintzas, K., Norton, L., Jewell, K., Macdonald, I.A., and Mansell, P.I. 2007. Exercise under hyperinsulinaemic conditions increases whole-body glucose disposal without affecting muscle glycogen utilisation in type 1 diabetes. Diabetologia, 50(2): 414-21. doi:10.1007/s00125-006-0520-0. PMID:17119916.

Consitt, L.A., Copeland, J.L., and Tremblay, M.S. 2002. Endogenous anabolic hormone responses to endurance versus resistance exercise and training in women. Sports Med. 32(1): 1-22. doi:10.2165/00007256-200232010-00001. PMID:11772159.

Copeland, J.L., Consitt, L.A., and Tremblay, M.S. 2002. Hormonal responses to endurance and resistance exercise in females aged 19-69 years. J. Gerontol. A. Biol. Sci. Med. Sci. 57(4): B158-65. doi:10.1093/gerona/57.4.B158. PMID:11909881.

Copeland, J.L., and Heggie, L. 2008. IGF-1 and IGFBP-3 during continuous and interval exercise. Int. J. Sports Med. 29(3): 182-187. doi:10.1055/s-2007-965114. PMID:17990213.

Davis, S.N., Fowler, S., and Costa, F. 2000a. Hypoglycemic counterregulatory responses differ between men and women with type 1 diabetes. Diabetes, 49(1): 65-72. PMID: 10615951.

Davis, S.N., Galassetti, P., Wasserman, D.H., and Tate, D. 2000b. Effects of gender on neuroendocrine and metabolic counterregulatory responses to exercise in normal man. J. Clin. Endocrinol. Metab. 85(1): 224-30. doi:10.1210/jcem.85.1.6328. PMID:10634391.

Devries, M.C. 2016. Sex-based differences in endurance exercise muscle metabolism: impact on exercise and nutritional strategies to optimize health and performance in women. Exp. Physiol. 101(2): 243-9. doi:10.1113/EP085369. PMID:24659076. 
Devries, M.C., Hamadeh, M.J., Graham, T.E., and Tarnopolsky, M.A. 2005. 17beta-estradiol supplementation decreases glucose rate of appearance and disappearance with no effect on glycogen utilization during moderate intensity exercise in men. J. Clin. Endocrinol. Metab. 90(11): 6218-25. doi:10.1210/jc.2005-0926. PMID:16118338

Devries, M.C., Hamadeh, M.J., Phillips, S.M., and Tarnopolsky, M.A. 2006. Menstrual cycle phase and sex influence muscle glycogen utilization and glucose turnover during moderate-intensity endurance exercise. Am. J. Physiol. Regul. Integr. Comp. Physiol. 291(4): R1120-8. doi:10.1152/ajpregu.00700.2005. PMID:16690766.

Devries, M.C., Lowther, S.A., Glover, A.W., Hamadeh, M.J., and Tarnopolsky, M.A. 2007. IMCL area density, but not IMCL utilization, is higher in women during moderate-intensity endurance exercise, compared with men. Am. J. Physiol. Regul. Integr. Comp. Physiol. 293(6): R2336-42. doi:10.1152/ajpregu.00510.2007. PMID:17913867.

Dube, M.C., Lavoie, C., and Weisnagel, S.J. 2013. Glucose or intermittent high-intensity exercise in glargine/glulisine users with T1DM. Med. Sci. Sports Exerc. 45(1): 3-7.

doi:10.1249/MSS.0b013e31826c6ad3. PMID:22895370

Eliakim, A., Nemet, D., Most, G., Rakover, N., Pantanowitz, M., and Meckel, Y. 2014. Effect of gender on the GH-IGF-I response to anaerobic exercise in young adults. J. Strength Cond. Res. 28(12): 3411-5. doi:10.1519/jsC.0000000000000605. PMID:24983853.

Enea, C., Boisseau, N., Fargeas-Gluck, M.A., Diaz, V., and Dugue, B. 2011. Circulating androgens in women: exercise-induced changes. Sports Med. 41(1): 1-15. doi:10.2165/11536920-000000000-00000. PMID: 21142281.

Esbjörnsson, M., Norman, B., Suchdev, S., Viru, M., Lindhgren, A., and Jansson, E. 2009. Greater growth hormone and insulin response in women than in men during repeated bouts of sprint exercise. Acta. Physiol. (Oxf). 197(2): 107-15. doi:10.1111/j.1748-1716.2009.01994.x. PMID:19432586. 
Esbjörnsson-Liljedahl, M., Sundberg, C.J., Norman, B., and Jansson, E. 1999. Metabolic response in type I and type II muscle fibers during a 30-s cycle sprint in men and women. J. Appl. Physiol. (1985), 87(4): 1326-32. doi:10.1152/jappl.1999.87.4.1326. PMID:10517759.

Fragala, M.S., Kraemer, W.J., Denegar, C.R., Maresh, C.M., Mastro, A.M., and Volek, J.S. 2011. Neuroendocrine-immune interactions and responses to exercise. Sports Med. 41(8): 621-39. doi:10.2165/11590430-000000000-00000. PMID:21780849.

Frystyk, J. 2004. Free insulin-like growth factors - measurements and relationships to growth hormone secretion and glucose homeostasis. Growth Horm. IGF Res. 14(5): 337-375.

doi:10.1016/j.ghir.2004.06.001. PMID:15336229.

Galassetti, P., Tate, D., Neill, R.A., Morrey, S., and Davis, S.N. 2002. Effect of gender on counterregulatory responses to euglycemic exercise in type 1 diabetes. J. Clin. Endocrinol. Metab. 87(11): 5144-50. doi:10.1210/jc.2002-020757. PMID:12414885.

Gatti, R., De Palo, E.F., Antonelli, G., and Spinella, P. 2012. IGF-1/IGFBP system: Metabolism outline and physical exercise. J. Endocrinol. Invest. 35(7): 699-707. doi:10.3275/8456. PMID:22712057. Gratas-Delamarche, A., Le Cam, R., Delamarche, P., Monnier, M., and Koubi, H. 1994. Lactate and catecholamine responses in male and female sprinters during a Wingate test. Eur. J. Appl. Physiol. Occup. Physiol. 68(4): 362-6. PMID:8055897.

Guelfi, K.J., Jones, T.W., and Fournier, P.A. 2005. The decline in blood glucose levels is less with intermittent high-intensity compared with moderate exercise in individuals with type 1 diabetes. Diabetes Care, 28(6): 1289-94. PMID:15920041.

Hamadeh, M.J., Devries, M.C., and Tarnopolsky, M.A. 2005. Estrogen supplementation reduces whole body leucine and carbohydrate oxidation and increases lipid oxidation in men during endurance exercise. J. Clin. Endocrinol. Metab. 90(6): 3592-9. doi:10.1210/jc.2004-1743. PMID:15755861.

Hedrington, M.S. and Davis, S.N. 2015. Sexual dimorphism in glucose and lipid metabolism during fasting, hypoglycemia, and exercise. Front. Endocrinol. (Lausanne), 6:61. doi:10.3389/fendo.2015.00061. PMID:25964778. 
Henderson, G.C. 2014. Sexual dimorphism in the effects of exercise on metabolism of lipids to support resting metabolism. Front. Endocrinol. (Lausanne), 5:162. doi:10.3389/fendo.2014.00162.

PMID:25339941.

Henderson, G.C., Fattor, J.A., Horning, M.A., Faghihnia, N., Johnson, M.L., Mau, T.L., et al. 2007. Lipolysis and fatty acid metabolism in men and women during the postexercise recovery period. J. Physiol. 584(Pt3): 963-81. doi:10.1113/jphysiol.2007.137331. PMID:17855762.

Henderson, G.C., Fattor, J.A., Horning, M.A., Faghihnia, N., Johnson, M.L., Luke-Zeitoun, M., et al. 2008. Glucoregulation is more precise in women than in men during postexercise recovery. Am. J. Clin. Nutr. 87(6): 1686-94. PMID:18541557.

Hornum, M., Cooper, D.M., Brasel, J.A., Bueno, A., and Sietsema, K.E. 1997. Exercise-induced changes in circulating growth factors with cyclic variation in plasma estradiol in women. J. Appl. Physiol. 82(6): 1946-1951. doi:10.1152/jappl.1997.82.8.1946. PMID:9173963.

Horton, T.J., Grunwald, G.K., Lavely, J., and Donahoo, W.T. 2006a. Glucose kinetics differ between women and men, during and after exercise. J. Appl. Physiol. (1985), 100(6): 1883-94. doi:10.1152/japplphysiol.01431.2005. PMID:16714415.

Horton, T.J., Miller, E.K., and Bourret, K. 2006b. No effect of menstrual cycle phase on glycerol or palmitate kinetics during 90 min of moderate exercise. J. Appl. Physiol. (1985), 100(3): 917-25. doi:10.1152/japplphysiol.00491.2005. PMID:16467391.

Horton, T.J., Pagliassotti, M.J., Hobbs, K., and Hill, J.O. 1998. Fuel metabolism in men and women during and after long-duration exercise. J. Appl. Physiol. (1985), 85(5): 1823-32.

doi:10.1152/jappl.1998.85.5.1823. PMID:9804587.

Hougham, K.A. and Ross, R. 2011. Evidence that the association between exercise intensity and insulin sensitivity is sex dependent. Appl. Physiol. Nutr. Metab. 36(5): 730-735. doi:10.1139/h11-093.

PMID:21999295. 
Hübinger, A., Ridderskamp, I., Lehmann, E., and Gries, F.A. 1985. Metabolic response to different forms of physical exercise in type I diabetics and the duration of the glucose lowering effect. Eur. J. Clin. Invest. 15(4): 197-203. PMID:2864257.

Isacco, L., Duche, P., and Boisseau, N. 2012. Influence of hormonal status on substrate utilization at rest and during exercise in the female population. Sports Med. 42(4): 327-42. doi:10.2165/11598900000000000-00000. PMID:22380007.

Iscoe, K.E. and Riddell, M.C. 2011. Continuous moderate-intensity exercise with or without intermittent high-intensity work: effects on acute and late glycaemia in athletes with Type 1 diabetes mellitus. Diabet. Med. 28(7): 824-32. doi:10.1111/j.1464-5491.2011.03274.x. PMID:21388440.

Jenni, S., Oetliker, C., Allemann, S., Ith, M., Tappy, L., Wuerth, S., et al. 2008. Fuel metabolism during exercise in euglycaemia and hyperglycaemia in patients with type 1 diabetes mellitus--a prospective single-blinded randomised crossover trial. Diabetologia, 51(8):1457-65. doi:10.1007/s00125-008-1045-5. PMID:18512043.

Jenni, S., Christ, E.R., and Stettler, C. 2010. Exercise-induced growth hormone response in euglycaemia and hyperglycaemia in partients with type 1 diabetes mellitus. Diabet. Med. 27(2): 230-233. doi:10.111/j.1464-5491.2009.02893.x. PMID:20546269.

Jimenez, C., Santiago, M., Sitler, M., Boden, G., and Homko, C. 2009. Insulin-sensitivity response to a single bout of resistive exercise in type 1 diabetes mellitus. J. Sport Rehabil. 18(4): 564-71. PMID:20108856.

Jurkowski, J.E., Jones, N.L., Walker, C., Younglai, E.V., and Sutton, J.R. 1978. Ovarian hormonal responses to exercise. J. Appl. Physiol. Respir. Environ. Exerc. Physiol. 44(1): 109-14. doi:10.1152/jappl.1978.44.1.109. PMID:627490.

Justice, T.D., Hammer, G.L., Davey, R.J., Paramalingam, N., Guelfi, K.J., Lewis, L., et al. 2015. Effect of antecedent moderate-intensity exercise on the glycemia-increasing effect of a 30-sec maximal sprint: a sex comparison. Physiol. Rep. 3(5): e12386. doi:10.14814/phy2.12386. PMID:26019290. 
Kraemer, R.R., Heleniak, R.J., Tryniecki, J.L., Kraemer, G.R., Okazaki, N.J., and Castracane, V.D. 1995. Follicular and luteal phase hormonal responses to low-volume resistive exercise. Med. Sci. Sports Exerc. 27(6): 809-17. PMID:7658941.

Kraemer, W.J., Fleck, S.J., Dziados, J.E., Harman, E.A., Marchitelli, L.J., Gordon, et al. 1993. Changes in hormonal concentrations after different heavy-resistance exercise protocols in women. J. Appl. Physiol. (1985), 75(2): 594-604. doi:10.1152/jappl.1993.75.2.594. PMID:8226457.

Kraemer, W.J., Gordon, S.E., Fleck, S.J., Marchitelli, L.J., Mello, R., Dziados, J.E., et al. 1991.

Endogenous anabolic hormonal and growth factor responses to heavy resistance exercise in males and females. Int. J. Sports Med. 12(2): 228-35. doi:10.1055/s-2007-1024673. PMID:1860749.

Kraemer, W.J., Staron, R.S., Hagerman, F.C., Hikida, R.S., Fry, A.C., Gordon, S.E., et al. 1998. The effects of short-term resistance training on endocrine function in men and women. Eur. J. Appl. Physiol. Occup. Physiol. 78(1): 69-76. doi:10.1007/s004210050389. PMID:1860749.

Leelayuwat, N., Tsintzas, K., Patel, K., and Macdonald, I.A. 2005. Metabolic responses to exercise after carbohydrate loads in healthy men and women. Med. Sci. Sports Exerc. 37(1): 1721-7. PMID:16260972. Linnamo, V., Pakarinen, A., Komi, P.V., Kraemer, W.J., and Hakkinen, K. 2005. Acute hormonal responses to submaximal and maximal heavy resistance and explosive exercises in men and women. J. Strength Cond. Res. 19(3): 566-71. doi:10.1519/R-15404.1. PMID:16095404.

Luk, H.Y., Kraemer, W.J., Szivak, T.K., Flanagan, S.D., Hooper, D.R., Kupchak, B.R., et al. 2015. Acute resistance exercise stimulates sex-specific dimeric immunoreactive growth hormone responses. Growth Horm. IGF Res. 25(3): 136-40. doi:10.1016/j.ghir.2015.02.002. PMID:25934139.

Maran, A., Pavan, P., Bonsembiante, B., Brugin, E., Ermolao, A., Avogaro, A., et al. 2010. Continuous glucose monitoring reveals delayed nocturnal hypoglycemia after intermittent high-intensity exercise in nontrained patients with type 1 diabetes. Diabetes Technol. Ther. 12(0): 763-8.

doi:10.1089/dia.2010.0038. PMID:20807120. 
Marliss, E.B., Kreisman, S.H., Manzon, A., Halter, J.B., Vranic, M., and Nessim, S.J. 2000. Gender differences in glucoregulatory responses to intense exercise. J. Appl. Physiol. (1985), 88(2): 457-66. doi:10.1152/jappl.2000.88.2.457. PMID:10658011.

McGregor, V.P., Greiwe, J.S., Banarer, S., and Cryer, P.E. 2002. Limited impact of vigorous exercise on defenses against hypoglycemia: relevance to hypoglycemia-associated autonomic failure. Diabetes, 51(5): 1485-92. PMID:11978646.

Mittendorfer, B., Horowitz, J.F., and Klein, S. 2002. Effect of gender on lipid kinetics during endurance exercise of moderate intensity in untrained subjects. Am. J. Physiol. Endocrinol. Metab. 283(1): E58-65. doi:10.1152/ajpendo.00504.2001. PMID:12067843.

Moser, O., Tschakert, G., Mueller, A., Groeschl, W., Pieber, T.R., Obermayer-Pietsch, B., et al. 2015. Effects of high-intensity interval exercise versus moderate continuous exercise on glucose homeostasis and hormone response in patients with type 1 diabetes mellitus using novel ultra-long-acting insulin. PLoS one, 10(8): e0136489. doi:10.1371/journal.pone.0136489. PMID:26317981.

Nindl, B.C., Kraemer, W.J., Gotshalk, L.A., Marx, J.O., Volek, J.S., Bush, F.A., et al. 2001. Testosterone responses after resistance exercise in women: influence of regional fat distribution. Int. J. Sport Nutr. Exerc. Metab. 11(4): 451-65. PMID:11915780.

Numao, S., Hayashi, Y., Katayama, Y., Matsuo, T., and Tanaka, K. 2009. Sex differences in substrate oxidation during aerobic exercise in obese men and postmenopausal obese women. Metabolism, 58(9): 1312-9. doi:10.1016/j.metabol.2009.04.015. PMID:19501865.

Palta, M., LeCaire, T.J., Sadek-Badawi, M., Herrera, V.M., and Danielson, K.K. 2014. The trajectory of IGF-1 across age and duration of type 1 diabetes. Diabetes Metab. Res. Rev. 30(8): 777-784.

doi:10.1002/dmrr.2554. PMID:24845759.

Perreault, L., Lavely, J.M., Bergman, B.C., and Horton, T.J. 2004. Gender differences in insulin action after a single bout of exercise. J. Appl. Physiol. (1985), 97(3): 1013-21.

doi:10.1152/japplphysiol.00186.2004. PMID:15145925. 
Pulido, J.M.E. and Salazar, M.A. 1999. Changes in insulin sensitivity, secretion and glucose effectiveness during menstrual cycle. Arch. Med. Res. 30(1): 19-22. doi:10.1016/S0188-0128(98)00008-6. PMID:10071420.

Pullinen, T., Nicol, C., MacDonald, E., and Komi, P.V. 1999. Plasma catecholamine responses to four resistance exercise tests in men and women. Eur. J. Appl. Physiol. 80(2): 125-131. doi:10.1007/s004210050568. PMID:10408323.

Pullinen, T., Mero, A., Huttunen, P., Pakarinen, A., and Komi, P.V. 2002. Resistance exercise-induced hormonal responses in men, women, and pubescent boys. Med. Sci. Sports. Exerc. 34(5): 806-13. PMID:11984299.

Purdon, C., Brousson, M., Nyveen, S.L., Miles, P.D., Halter, J.B., Vranic, M., et al. 1993. The roles of insulin and catecholamines in the glucoregulatory response during intense exercise and early recovery in insulin-dependent diabetic and control subjects. J. Clin. Endocrinol. Metab. 76(3): 566-73. doi:10.1210/jcem.76.3.8445012. PMID:8445012. Raguso, C.A., Coggan, A.R., Gastaldelli, A., Sidossis, L.S., Bastyr, E.J. 3rd, and Wolfe, R.R. 1995. Lipid and carbohydrate metabolism in IDDM during moderate and intense exercise. Diabetes, 44(9): 1066-74. PMID:7657030.

Ramires, P.R., Forjaz, C.L., Silva, M.E., Diament, J., Nicolau, W., Liberman, B., et al. 1993. Exercise tolerance is lower in type I diabetics compared with normal young men. Metabolism, 42(2): 191-5. PMID:8474316.

Riddell, M.C., Partington, S.L., Stupka, N., Armstrong, D., Rennie, C., and Tarnopolsky, M.A. 2003. Substrate utilization during exercise performed with and without glucose ingestion in female and male endurance trained athletes. Int. J. Sport Nutr. Exerc. Metab. 13(4): 407-21. PMID:14967866.

Robitaille, M., Dube, M.C., Weisnagel, S.J., Prud'homme, D., Massicotte, D., Peronnet, F., et al. 2007. Substrate source utilization during moderate intensity exercise with glucose ingestion in type 1 diabetic patients. J. Appl. Physiol. (1985), 103(1): 119-24. doi:10.1152/japplphysiol.01462.2006.

PMID:17431081. 
Roepstorff, C., Steffensen, C.H., Madsen, M., Stallknecht, B., Kanstrup, I.L., Richter, E.A., et al. 2002. Gender differences in substrate utilization during submaximal exercise in endurance-trained subjects. Am. J. Physiol. Endocrinol. Metab. 282(2): E435-47. doi:10.1152/ajpendo.00266.200. PMID:11788377. Sarafian, D., Schutz, Y., Montani, J.P., Dulloo, A.G., and Miles-Chan, J.L. 2016. Sex difference in substrate oxidation during low-intensity isometric exercise in young adults. Appl. Physiol. Nutr. Metab. 41(9): 977-84. doi:10.1139/apnm-2016-0127. PMID:27540628.

Schmidt, S.L., Bessesen, D.H., Stotz, S., Peelor, F.F., 3rd, Miller, B.F., and Horton, T.J. 2014. Adrenergic control of lipolysis in women compared with men. J. Appl. Physiol. (1985), 117(9): 1008-19. doi:10.1152/japplphysiol.00003.2014. PMID:25190743.

Steffensen, C.H., Roepstorff, C., Madsen, M., and Kiens, B. 2002. Myocellular triacylglycerol breakdown in females but not in males during exercise. Am. J. Physiol. Endocrinol. Metab. 282(3): E634-42. doi:10.1152/ajpendo.00078.2001. PMID:11832367. Tarnopolsky, L.J., MacDougall, J.D., Atkinson, S.A., Tarnopolsky, M.A., and Sutton, J.R. 1990. Gender differences in substrate for endurance exercise. J. Appl. Physiol. (1985), 68(1): 302-8. doi:10.1152/jappl.1990.68.1.302. PMID:2179207. Tarnopolsky, M.A. 2008. Sex differences in exercise metabolism and the role of 17-beta estradiol. Med. Sci. Sports Exerc. 40(4): 648-54. doi:10.1249/MSS.0b013e31816212ff. PMID:18317381.

Thabit, H. and Leelarathna, L. (2016). Basal insulin delivery reduction for exercise in type 1 diabetes: finding the sweet spot. Diabetologia, 59(8): 1628-1631. doi:10.1007/s00125-016-4010-8. PMID:27287376.

Tonoli, C., Heyman, E., Buyse, L., Roelands, B., Piacentini, M.F., Bailey, S., et al. 2014. Neurotrophins and cognitive functions in T1D compared with healthy controls: effects of a high-intensity exercise. Appl. Phyiol. Nutr. Metab. 40(1): 20-27. doi:10.1139/apnm-2014-0098. PMID:25525862.

Tremblay, J., Peronnet, F., Massicotte, D., and Lavoie, C. 2010. Carbohydrate supplementation and sex differences in fuel selection during exercise. Med. Sci. Sports Exerc. 42(7): 1314-23. doi:10.1249/MSS.0b013e3181 cbba0b. PMID:20019632. 
Valdes, C.T. and Elkind-Hirsch, K.E. 1991. Intravenous glucose tolerance test-derived insulin sensitivity changes during the menstrual cycle. J. Clin. Endocrinol. Metab. 72(3): 642-6. doi:10.1210/jcem-72-3-642. PMID:1997519.

Venables, M.C., Achten, J., and Jeukendrup, A.E. 2005. Determinants of fat oxidation during exercise in healthy men and women: a cross-sectional study. J. Appl. Physiol. (1985), 98(1): 160-7. doi:10.1152/japplphysiol.00662.2003. PMID:15333616.

Vincent, S., Berthon, P., Zouhal, H., Moussa, E., Catheline, M., Bentue-Ferrer, D., et al. 2004. Plasma glucose, insulin and catecholamine responses to a Wingate test in physically active women and men. Eur. J. Appl. Physiol. 91(1): 15-21. doi:10.1007/s00421-003-0957-5. PMID:14551777.

Vislocky, L.M., Gaine, P.C., Pikosky, M.A., Martin, W.F., and Rodriguez, N.R. 2008. Gender impacts the post-exercise substrate and endocrine response in trained runners. J. Int. Soc. Sports Nutr. 5:7. doi:10.1186/1550-2783-5-7. PMID:18302755.

Wahrenberg, H., Lonnqvist, F., Engfeldt, P., and Arner, P. 1989. Abnormal action of catecholamines on lipolysis in adipocytes of type I diabetic patients treated with insulin. Diabetes, 38(4): 524-33. PMID:2647559.

Wallis, G.A., Dawson, R., Achten, J., Webber, J., and Jeukendrup, A.E. 2006. Metabolic response to carbohydrate ingestion during exercise in males and females. Am. J. Physiol. Endocrinol. Metab. 290(4): E708-15. doi:10.1152/ajpendo.00357.2005. PMID:16278245.

Wideman, L., Weltman, J.Y., Shah, N., Story, S., Veldhuis, J.D., and Weltman, A. 1999. Effects of gender on exercise-induced growth hormone release. J. Appl. Physiol. (1985), 87(3): 1154-62. doi:10.1152/jappl.1999.87.3.1154. PMID:10484590.

Wiecek, M., Maciejczyk, M., Szymura, J., and Szygula, Z. 2017. Sex differences in oxidative stress after eccentric and concentric exercise. Redox Rep. 22(6):478-485. doi:10.1080/13510002.2017.1304195. PMID:28320258. 
Yardley, J.E., Kenny, G.P., Perkins, B.A., Riddell, M.C., Balaa, N., Malcolm, J., et al. 2013. Resistance versus aerobic exercise: acute effects on glycemia in type 1 diabetes. Diabetes Care, 36(3): 537-42. doi:10.2337/dc12-0963. PMID:23172972.

Yardley, J.E., Sigal, R.J., Riddell, M.C., Perkins, B.A., and Kenny, G.P. 2014. Performing resistance exercise before versus after aerobic exercise influences growth hormone secretion in type 1 diabetes. Appl. Physiol. Nutr. Metab. 39(2): 262-5. doi:10.1139/apnm-2013-0329. PMID:24476484.

Yardley, J.E., Zaharieva, D.P., Jarvis, C., and Riddell, M.C. 2015. The "ups" and "downs" of a bike race in people with type 1 diabetes: dramatic differences in strategies and blood glucose responses in the Paristo-Ancaster Spring Classic. Can. J. Diabetes, 39(2):105-10. doi:10.1016/j.jcjd.2014.09.003. PMID:25492557.

Zderic, T.W., Coggan, A.R., and Ruby, B.C. 2001. Glucose kinetics and substrate oxidation during exercise in the follicular and luteal phases. J. Appl. Physiol. (1985), 90(2): 447-53. doi:10.1152/jappl.2001.90.2.447. PMID:11160041.

Zehnder, M., Ith, M., Kreis, R., Saris, W., Boutellier, U., and Boesch, C. 2005. Gender-specific usage of intramyocellular lipids and glycogen during exercise. Med. Sci. Sports. Exerc. 37(9): 1517-24.

PMID:16177603.

Zinman, B., Murray, F.T., Vranic, M., Albisser, A.M., Leibel, B.S., Mc Clean, P.A., et al. 1977. Glucoregulation during moderate exercise in insulin treated diabetics. J. Clin. Endocrinol. Metab. 45(4): 641-52. doi:10.1210/jcem-45-4-641. PMID:914970. 
Table 1. Summary of studies on sex-related differences in aerobic exercise.

\begin{tabular}{|c|c|c|c|c|c|c|c|c|c|c|c|c|}
\hline \multirow[b]{3}{*}{ Study } & \multicolumn{6}{|c|}{ Design } & \multicolumn{6}{|c|}{ Change during exercise } \\
\hline & \multicolumn{2}{|c|}{ Participants } & \multicolumn{4}{|c|}{ Exercise } & \multirow[b]{2}{*}{ Fuel Selection } & \multirow[b]{2}{*}{ Catecholamine } & \multirow[b]{2}{*}{$\begin{array}{l}\text { Growth } \\
\text { Hormone }\end{array}$} & \multirow[b]{2}{*}{ Estrogen } & \multirow[b]{2}{*}{ Glucagon } & \multirow[b]{2}{*}{$\begin{array}{l}\text { Blood } \\
\text { Glucose }\end{array}$} \\
\hline & $\begin{array}{l}\mathbf{N} \\
\mathbf{M} / \mathbf{F}\end{array}$ & $\begin{array}{l}\text { Training } \\
\text { Status }\end{array}$ & Type & Duration & Intensity & $\begin{array}{l}\text { Prandial } \\
\text { State }\end{array}$ & & & & & & \\
\hline $\begin{array}{l}\text { Riddell et al. } \\
2003\end{array}$ & $7 / 7$ & ET & Cycle & $90 \mathrm{~min}$ & $\begin{array}{l}60 \% \\
\mathrm{VO}_{2} \max \end{array}$ & CHO load & $\begin{array}{l}\text { Higher RER in } \\
\text { males }\end{array}$ & -- & -- & -- & -- & $\begin{array}{l}\text { Similar } \\
\text { levels }\end{array}$ \\
\hline $\begin{array}{l}\text { Horton et al. } \\
1998\end{array}$ & $14 / 14$ & $\mathrm{~T} / \mathrm{UT}$ & Cycle & $120 \mathrm{~min}$ & $\begin{array}{l}40 \% \\
\mathrm{VO}_{2} \max \end{array}$ & Fasted & $\begin{array}{l}\text { Higher RER in } \\
\text { males }\end{array}$ & $\begin{array}{l}\text { Greater increase } \\
\text { of } \mathrm{E} \text { and } \mathrm{NE} \text { in } \\
\text { males }\end{array}$ & -- & $\begin{array}{l}\text { Greater } \\
\text { increase in } \\
\text { females }\end{array}$ & -- & $\begin{array}{l}\text { Higher } \\
\text { levels in } \\
\text { males }\end{array}$ \\
\hline $\begin{array}{l}\text { Mittendorfer } \\
\text { et al. } 2002\end{array}$ & $5 / 5$ & UT & Cycle & $90 \mathrm{~min}$ & $\begin{array}{l}50 \% \\
\mathrm{VO}_{2} \max \end{array}$ & Fasted & $\begin{array}{l}\text { Similar RER. } \\
\text { Higher lipolytic } \\
\text { rate in females. }\end{array}$ & $\begin{array}{l}\text { Similar increase } \\
\text { of } E \text { and NE }\end{array}$ & -- & -- & -- & -- \\
\hline $\begin{array}{l}\text { Davis et al. } \\
\text { 2000b }\end{array}$ & $8 / 8$ & UT & Cycle & $90 \mathrm{~min}$ & $80 \%$ AT & Fasted & $\begin{array}{l}\text { Higher } \mathrm{CHO} \\
\text { oxidation in } \\
\text { males }\end{array}$ & $\begin{array}{l}\text { Greater increase } \\
\text { of } E \text { and } N E \text { in } \\
\text { males }\end{array}$ & $\begin{array}{l}\text { Similar } \\
\text { increase }\end{array}$ & & $\begin{array}{l}\text { Similar } \\
\text { increase }\end{array}$ & -- \\
\hline \multirow[t]{2}{*}{$\begin{array}{l}\text { Henderson et } \\
\text { al. } 2007\end{array}$} & \multirow[t]{2}{*}{$10 / 10$} & \multirow[t]{2}{*}{ UT } & \multirow[t]{2}{*}{ Cycle } & $90 \mathrm{~min}$ & $\begin{array}{l}45 \% \\
\mathrm{VO}_{2} \max \end{array}$ & \multirow{2}{*}{$\begin{array}{l}3 \mathrm{~h} \text { after } \\
\text { standard } \\
\text { breakfast }\end{array}$} & \multirow[t]{2}{*}{$\begin{array}{l}\text { Higher RER in } \\
\text { males }\end{array}$} & Similar increase & \multirow{2}{*}{$\begin{array}{l}\text { Sig. } \\
\text { increase in } \\
\text { males } \\
\text { only }\end{array}$} & \multirow[t]{2}{*}{--} & \multirow[t]{2}{*}{--} & \multirow[t]{2}{*}{--} \\
\hline & & & & $60 \mathrm{~min}$ & $\begin{array}{l}65 \% \\
\mathrm{VO}_{2} \max \end{array}$ & & & $\begin{array}{l}\text { Greater increase } \\
\text { of } \mathrm{E} \text { in males }\end{array}$ & & & & \\
\hline $\begin{array}{l}\text { Steffensen et } \\
\text { al. } 2002\end{array}$ & $21 / 21$ & $\begin{array}{l}\mathrm{UT} / \\
\mathrm{MT} / \\
\mathrm{ET}\end{array}$ & Cycle & $90 \mathrm{~min}$ & $\begin{array}{l}60 \% \\
\mathrm{VO}_{2} \max \end{array}$ & Fasted & $\begin{array}{l}\text { Similar RER. } \\
\text { IMCL depletion } \\
\text { in females only. }\end{array}$ & $\begin{array}{l}\text { Greater increase } \\
\text { of E in males. } \\
\text { Similar NE } \\
\text { increase. }\end{array}$ & -- & $\begin{array}{l}\text { Higher in } \\
\text { females }\end{array}$ & -- & -- \\
\hline $\begin{array}{l}\text { Devries et al. } \\
2006\end{array}$ & $13 / 11$ & MT & Cycle & $90 \mathrm{~min}$ & $\begin{array}{l}65 \% \\
\mathrm{VO}_{2} \max \end{array}$ & Fasted & $\begin{array}{l}\text { Higher RER in } \\
\text { males }\end{array}$ & -- & -- & $\begin{array}{l}\text { Similar } \\
\text { levels }\end{array}$ & -- & $\begin{array}{l}\text { Similar } \\
\text { levels }\end{array}$ \\
\hline $\begin{array}{l}\text { Tremblay et } \\
\text { al. } 2010\end{array}$ & $6 / 12$ & MT & Cycle & $120 \mathrm{~min}$ & $\begin{array}{l}57 \% \\
\mathrm{VO}_{2} \max \end{array}$ & $\begin{array}{l}\text { CHO load } \\
\text { Water }\end{array}$ & $\begin{array}{l}\text { Similar RER } \\
\text { Higher RER in } \\
\text { males }\end{array}$ & -- & -- & -- & -- & $\begin{array}{l}\text { Similar } \\
\text { levels }\end{array}$ \\
\hline $\begin{array}{l}\text { Roepstorff et } \\
\text { al. } 2002\end{array}$ & $7 / 7$ & ET & Cycle & $90 \mathrm{~min}$ & $\begin{array}{l}58 \% \\
\mathrm{VO}_{2} \max \end{array}$ & Fasted & $\begin{array}{l}\text { Similar RER. } \\
\text { Greater IMCL } \\
\text { depletion in } \\
\text { females. }\end{array}$ & $\begin{array}{l}\text { Similar increase } \\
\text { of } E \text { and NE }\end{array}$ & -- & -- & -- & $\begin{array}{l}\text { Similar } \\
\text { levels }\end{array}$ \\
\hline $\begin{array}{l}\text { Zehnder et } \\
\text { al. } 2005\end{array}$ & $9 / 9$ & ET & Cycle & $180 \mathrm{~min}$ & $\begin{array}{l}50 \% \\
\mathrm{VO}_{2} \max \end{array}$ & Fasted & $\begin{array}{l}\text { Similar RER. } \\
\text { Greater IMCL } \\
\text { depletion in } \\
\text { males }\end{array}$ & -- & -- & -- & -- & $\begin{array}{l}\text { Similar } \\
\text { levels }\end{array}$ \\
\hline $\begin{array}{l}\text { Devries et al. } \\
2007\end{array}$ & $17 / 19$ & $\begin{array}{l}\text { MT/ } \\
\text { ET }\end{array}$ & Cycle & $90 \mathrm{~min}$ & $\begin{array}{l}\sim 63 \% \\
\mathrm{VO}_{2} \max \end{array}$ & Fasted & $\begin{array}{l}\text { Higher RER in } \\
\text { males. Similar } \\
\text { IMCL use. }\end{array}$ & -- & -- & -- & -- & -- \\
\hline
\end{tabular}

Note: M, male; F, female; UT, untrained; MT, moderately trained; ET, endurance trained; E, epinephrine; NE, norepinephrine; RER, respiratory exchange ratio; IMCL, intramyocellular lipids; CHO, carbohydrate; Sig, significant. 
Table 1. Summary of studies on sex-related differences in aerobic exercise, continued.

\begin{tabular}{|c|c|c|c|c|c|c|c|c|c|c|c|c|}
\hline \multirow[b]{3}{*}{ Study } & \multicolumn{6}{|c|}{ Design } & \multicolumn{6}{|c|}{ Change during exercise } \\
\hline & \multicolumn{2}{|c|}{ Participants } & \multicolumn{4}{|c|}{ Exercise } & \multirow[b]{2}{*}{$\begin{array}{l}\text { Fuel } \\
\text { Selection }\end{array}$} & \multirow[b]{2}{*}{ Catecholamine } & \multirow[b]{2}{*}{$\begin{array}{l}\text { Growth } \\
\text { Hormone }\end{array}$} & \multirow[b]{2}{*}{ Estrogen } & \multirow[b]{2}{*}{ Glucagon } & \multirow[b]{2}{*}{$\begin{array}{l}\text { Blood } \\
\text { Glucose }\end{array}$} \\
\hline & $\begin{array}{l}\mathbf{N} \\
\mathbf{M} / \mathbf{F}\end{array}$ & $\begin{array}{l}\text { Training } \\
\text { Status }\end{array}$ & Type & Duration & Intensity & $\begin{array}{l}\text { Prandial } \\
\text { State }\end{array}$ & & & & & & \\
\hline $\begin{array}{l}\text { Tarnopolsky } \\
\text { et al. } 1990\end{array}$ & $6 / 6$ & MT & Run & $\begin{array}{l}90-101 \\
\min (15.5 \\
\mathrm{km})\end{array}$ & $\begin{array}{l}\sim 65 \% \\
\mathrm{VO}_{2} \max \end{array}$ & Fasted & $\begin{array}{l}\text { Higher RER } \\
\text { and glycogen } \\
\text { use in males. }\end{array}$ & $\begin{array}{l}\text { Similar NE. } \\
\text { Higher E in } \\
\text { males. }\end{array}$ & $\begin{array}{l}\text { Increased } \\
\text { in males } \\
\text { only. }\end{array}$ & -- & $\begin{array}{l}\text { Greater } \\
\text { increase in } \\
\text { males }\end{array}$ & $\begin{array}{l}\text { Higher in } \\
\text { females. }\end{array}$ \\
\hline $\begin{array}{l}\text { Leelayuwat } \\
\text { et al. } 2005\end{array}$ & $7 / 7$ & UT & Cycle & $60 \mathrm{~min}$ & $\begin{array}{l}50 \% \\
\mathrm{VO}_{2} \max \end{array}$ & CHO load & Similar RER. & $\begin{array}{l}\text { Similar E. } \\
\text { Lower NE in } \\
\text { males. }\end{array}$ & -- & -- & -- & $\begin{array}{l}\text { Similar } \\
\text { levels }\end{array}$ \\
\hline \multirow{2}{*}{$\begin{array}{l}\text { Wallis et al. } \\
2006\end{array}$} & \multirow[t]{2}{*}{$8 / 8$} & \multirow[t]{2}{*}{ MT } & \multirow[t]{2}{*}{ Cycle } & \multirow[t]{2}{*}{$120 \mathrm{~min}$} & \multirow{2}{*}{$\begin{array}{l}\sim 67 \% \\
\mathrm{VO}_{2} \max \end{array}$} & CHO load & \multirow[t]{2}{*}{ Similar RER } & \multirow[t]{2}{*}{--} & \multirow[t]{2}{*}{--} & \multirow[t]{2}{*}{--} & \multirow[t]{2}{*}{-} & \multirow{2}{*}{$\begin{array}{l}\text { Similar } \\
\text { levels }\end{array}$} \\
\hline & & & & & & Water & & & & & & \\
\hline \multirow[t]{2}{*}{$\begin{array}{l}\text { Henderson et } \\
\text { al. } 2008\end{array}$} & \multirow[t]{2}{*}{$10 / 8$} & \multirow[t]{2}{*}{ MT } & \multirow[t]{2}{*}{ Cycle } & $90 \mathrm{~min}$ & $\begin{array}{l}45 \% \\
\mathrm{VO}_{2} \max \end{array}$ & \multirow{2}{*}{$\begin{array}{l}3 \mathrm{~h} \text { after } \\
\text { standard } \\
\text { breakfast }\end{array}$} & \multirow[t]{2}{*}{--} & \multirow[t]{2}{*}{--} & \multirow[t]{2}{*}{--} & \multirow[t]{2}{*}{--} & \multirow{2}{*}{$\begin{array}{l}\text { Greater } \\
\text { increase in } \\
\text { males }\end{array}$} & \multirow{2}{*}{$\begin{array}{l}\text { Quicker } \\
\text { recovery } \\
\text { in } \\
\text { females. }\end{array}$} \\
\hline & & & & $60 \mathrm{~min}$ & $\begin{array}{l}65 \% \\
\mathrm{VO}_{2} \max \end{array}$ & & & & & & & \\
\hline $\begin{array}{l}\text { Numao et al. } \\
2009\end{array}$ & $10 / 10$ & Obese & Cycle & $40 \mathrm{~min}$ & $\begin{array}{l}50 \% \\
\mathrm{VO}_{2} \max \end{array}$ & Fasted & $\begin{array}{l}\text { Higher RER } \\
\text { in males }\end{array}$ & $\begin{array}{l}\text { Higher E and } \\
\mathrm{NE} \text { in males }\end{array}$ & -- & $\begin{array}{l}\text { Similar } \\
\text { levels }\end{array}$ & -- & -- \\
\hline $\begin{array}{l}\text { Vislocky et } \\
\text { al. } 2008\end{array}$ & $6 / 6$ & ET & Run & $75 \mathrm{~min}$ & $\begin{array}{l}70 \% \\
\mathrm{VO}_{2} \max \end{array}$ & Fasted & -- & -- & $\begin{array}{l}\text { Increased } \\
\text { in males } \\
\text { only. }\end{array}$ & -- & -- & $\begin{array}{l}\text { Increased } \\
\text { in females } \\
\text { only }\end{array}$ \\
\hline $\begin{array}{l}\text { Perreault et } \\
\text { al. } 2004\end{array}$ & $10 / 10$ & MT & Cycle & $90 \mathrm{~min}$ & $\begin{array}{l}85 \% \text { lactate } \\
\text { threshold }\end{array}$ & Fasted. & -- & Similar levels & -- & -- & $\begin{array}{l}\text { Greater } \\
\text { increase in } \\
\text { males }\end{array}$ & -- \\
\hline $\begin{array}{l}\text { Boisseau et } \\
\text { al. } 2000\end{array}$ & $10 / 12$ & MT & Cycle & $30 \mathrm{~min}$ & $\begin{array}{l}60 \% \\
\mathrm{VO}_{2} \max \end{array}$ & $\begin{array}{l}\text { CHO } \\
\text { ingestion } \\
\text { (oral) }\end{array}$ & -- & Similar levels & -- & -- & -- & $\begin{array}{l}\text { Higher in } \\
\text { males }\end{array}$ \\
\hline $\begin{array}{l}\text { Horton et al. } \\
\text { 2006a }\end{array}$ & $12 / 10$ & MT & Cycle & $90 \mathrm{~min}$ & $\begin{array}{l}75 \% \text { of } \\
\text { lactate } \\
\text { threshold }\end{array}$ & Fasted & $\begin{array}{l}\text { Lower CHO } \\
\text { oxidation in } \\
\text { females. }\end{array}$ & $\begin{array}{l}\text { Similar NE. } \\
\text { Higher E in } \\
\text { males. }\end{array}$ & -- & -- & $\begin{array}{l}\text { Greater } \\
\text { increase in } \\
\text { males. }\end{array}$ & $\begin{array}{l}\text { Similar } \\
\text { levels }\end{array}$ \\
\hline $\begin{array}{l}\text { Wiecek et al. } \\
2017\end{array}$ & $10 / 10$ & MT & $\begin{array}{l}\text { Tread- } \\
\text { mill }\end{array}$ & $\begin{array}{l}45 \\
\text { minutes }\end{array}$ & $\begin{array}{l}50-55 \% \\
\mathrm{VO}_{2} \max \end{array}$ & $\begin{array}{l}2 \mathrm{~h} \text { after } \\
\text { light meal }\end{array}$ & $\begin{array}{l}\text { Higher lipid } \\
\text { oxidation in } \\
\text { females. }\end{array}$ & -- & -- & -- & -- & -- \\
\hline $\begin{array}{l}\text { Venables et } \\
\text { al. } 2005\end{array}$ & $\begin{array}{l}157 / \\
143\end{array}$ & $\begin{array}{l}\text { UT/MT/E } \\
\mathrm{T}\end{array}$ & $\begin{array}{l}\text { Tread- } \\
\text { mill }\end{array}$ & -- & $\begin{array}{l}\text { Graded test } \\
\text { to } \\
\text { exhaustion }\end{array}$ & $\begin{array}{l}\text { After 4-h } \\
\text { fast }\end{array}$ & $\begin{array}{l}\text { Higher } \mathrm{CHO} \text {, } \\
\text { lower fat } \\
\text { oxidation in } \\
\text { males. }\end{array}$ & -- & -- & -- & -- & -- \\
\hline
\end{tabular}

Note: M, male; F, female; UT, untrained; MT, moderately trained; ET, endurance trained; E, epinephrine; NE, norepinephrine; RER, respiratory exchange ratio; CHO, carbohydrate. 
Table 2. Summary of studies on sex-related differences in high-intensity anaerobic exercise.

\begin{tabular}{|c|c|c|c|c|c|c|c|c|c|c|c|c|}
\hline \multirow[b]{3}{*}{ Study } & \multicolumn{6}{|c|}{ Design } & \multicolumn{6}{|c|}{ Change during exercise } \\
\hline & \multicolumn{2}{|c|}{ Participants } & \multicolumn{4}{|c|}{ Exercise } & \multirow[b]{2}{*}{$\begin{array}{l}\text { Fuel } \\
\text { Selection }\end{array}$} & \multirow[b]{2}{*}{ Catecholamine } & \multirow[b]{2}{*}{$\begin{array}{l}\text { Growth } \\
\text { Hormone }\end{array}$} & \multirow[b]{2}{*}{ Estrogen } & \multirow[b]{2}{*}{ Glucagon } & \multirow[b]{2}{*}{$\begin{array}{l}\text { Blood } \\
\text { Glucose }\end{array}$} \\
\hline & $\begin{array}{l}\mathbf{N} \\
\mathbf{M} / \mathbf{F}\end{array}$ & $\begin{array}{l}\text { Training } \\
\text { Status }\end{array}$ & Type & Duration & Intensity & $\begin{array}{l}\text { Prandial } \\
\text { State }\end{array}$ & & & & & & \\
\hline $\begin{array}{l}\text { Justice et al. } \\
2015\end{array}$ & $8 / 7$ & MT & Cycle & $30 \mathrm{sec}$ & $\begin{array}{l}\text { Maximal } \\
\text { (Wingate) }\end{array}$ & $\begin{array}{l}3 \mathrm{~h} 15 \mathrm{~min} \\
\text { after } \\
\text { breakfast } \\
\text { and } 60 \\
\text { min cycle }\end{array}$ & -- & $\begin{array}{l}\text { Higher } \mathrm{E} \text { and NE } \\
\text { levels in males. }\end{array}$ & $\begin{array}{l}\text { Higher levels in } \\
\text { males. }\end{array}$ & -- & $\begin{array}{l}\text { Similar } \\
\text { levels }\end{array}$ & $\begin{array}{l}\text { Similar } \\
\text { levels }\end{array}$ \\
\hline $\begin{array}{l}\text { Gratas- } \\
\text { Delamarche } \\
\text { et al. } 1994\end{array}$ & $6 / 6$ & $\mathrm{ST}$ & Cycle & $30 \mathrm{sec}$ & $\begin{array}{l}\text { Maximal } \\
\text { (Wingate) }\end{array}$ & Fasted & -- & $\begin{array}{l}\text { Higher E levels } \\
\text { in males. Similar } \\
\text { NE. }\end{array}$ & -- & -- & -- & -- \\
\hline $\begin{array}{l}\text { Eliakim et al. } \\
2014\end{array}$ & $12 / 16$ & MT & Cycle & $30 \mathrm{sec}$ & $\begin{array}{l}\text { Maximal } \\
\text { (Wingate) }\end{array}$ & & -- & -- & $\begin{array}{l}\text { Higher levels in } \\
\text { females. }\end{array}$ & -- & -- & -- \\
\hline $\begin{array}{l}\text { Esbjörnsson } \\
\text { et al. } 2009\end{array}$ & $10 / 8$ & MT & Cycle & $\begin{array}{l}3 \text { sets of } \\
30 \sec (20 \\
\text { min rest })\end{array}$ & $\begin{array}{l}\text { Maximal } \\
\text { (Wingate) }\end{array}$ & Fasted & -- & -- & $\begin{array}{l}\text { Similar levels. } \\
\text { Earlier peak in } \\
\text { females. }\end{array}$ & -- & -- & $\begin{array}{l}\text { Higher in } \\
\text { males. }\end{array}$ \\
\hline $\begin{array}{l}\text { Esbjörnsson- } \\
\text { Liljedahl et } \\
\text { al. } 1999\end{array}$ & $20 / 19$ & MT & Cycle & $30 \mathrm{sec}$ & $\begin{array}{l}\text { Maximal } \\
\text { (Wingate) }\end{array}$ & Fasted & $\begin{array}{l}\text { Smaller } \\
\text { glycogen } \\
\text { depletion } \\
\text { in females }\end{array}$ & -- & -- & -- & -- & -- \\
\hline $\begin{array}{l}\text { Vincent et al. } \\
2004\end{array}$ & $8 / 8$ & MT & Cycle & $30 \mathrm{sec}$ & $\begin{array}{l}\text { Maximal } \\
\text { (Wingate) }\end{array}$ & $\begin{array}{l}1 \mathrm{~h} 30 \mathrm{~min} \\
\text { after } \\
\text { standard } \\
\text { breakfast }\end{array}$ & -- & $\begin{array}{l}\text { Similar levels of } \\
\text { E and NE. }\end{array}$ & -- & $\begin{array}{l}\text { Increased } \\
\text { in females }\end{array}$ & -- & $\begin{array}{l}\text { Higher in } \\
\text { females }\end{array}$ \\
\hline $\begin{array}{l}\text { Marliss et al. } \\
2000\end{array}$ & $16 / 12$ & MT & Cycle & $14 \mathrm{~min}$ & $\begin{array}{l}88 \% \\
\mathrm{VO}_{2} \max \end{array}$ & Fasted & $\begin{array}{l}\text { Similar } \\
\text { RER. }\end{array}$ & $\begin{array}{l}\text { Similar levels of } \\
\text { E and NE. }\end{array}$ & -- & -- & $\begin{array}{l}\text { Similar } \\
\text { levels }\end{array}$ & $\begin{array}{l}\text { Higher in } \\
\text { females. }\end{array}$ \\
\hline
\end{tabular}


Table 3. Summary of studies on sex-related differences in resistance exercise.

$$
\text { Design }
$$

\section{Change during exercise}

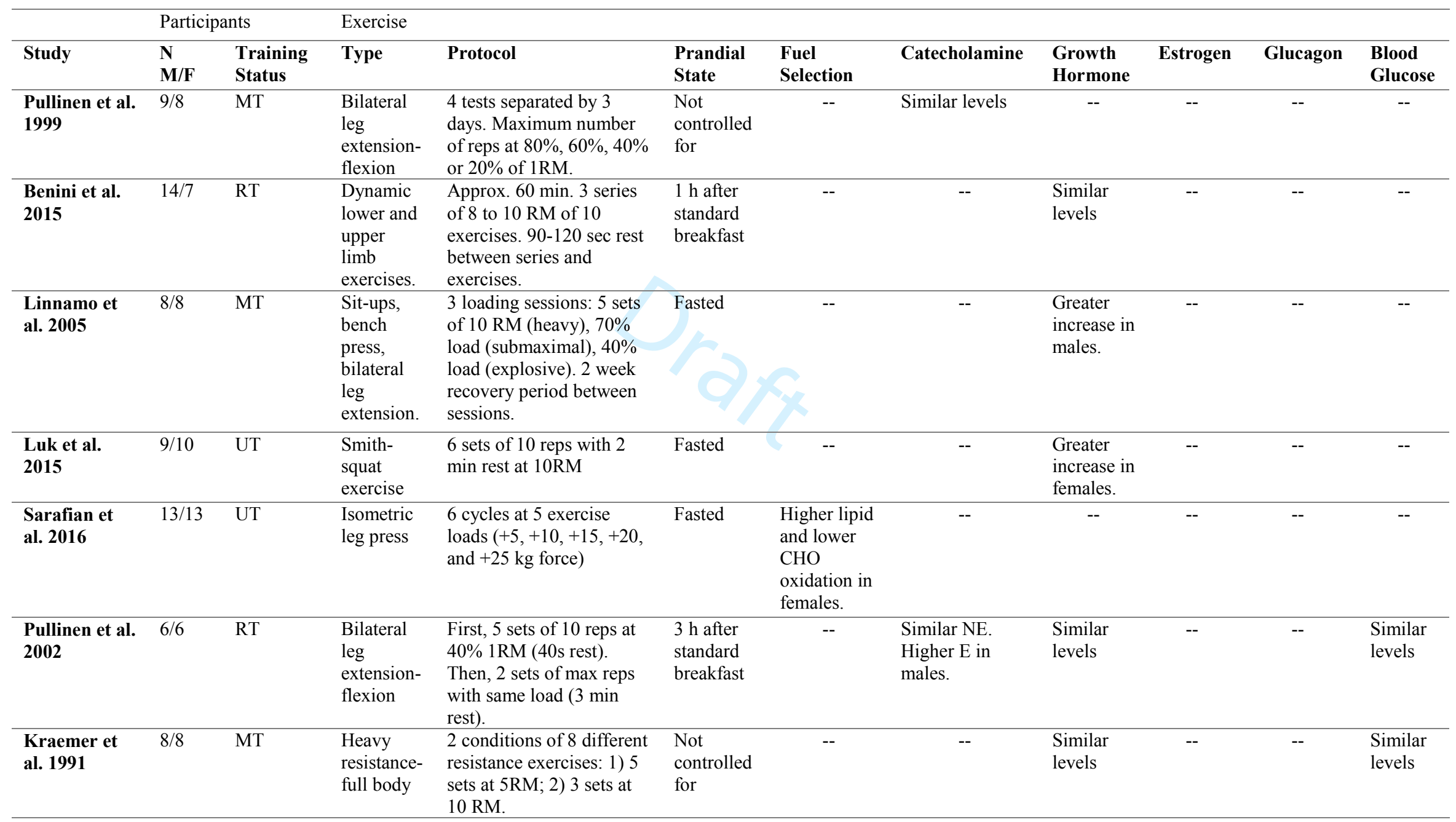

Note: M, male; F, female; UT, untrained; MT, moderately trained; RT, resistance trained; E, epinephrine; NE, norepinephrine; RER, respiratory exchange ratio; CHO, carbohydrate; $\mathrm{RM}$, repetition maximum; Approx, approximately. 
https://mc06.manuscriptcentral.com/apnm-pubs 